\title{
Effect of Different Proportions of Probiotics on Immunological Blood Parameters of Babcock Laying Hens Strain
}

\author{
Moustafa Abed-Almajeed ${ }^{1}$, Mahdi Salih Mohammad Al-Kerwi ${ }^{2, a)}$, Omar Mardenli ${ }^{1, b)}$, Faez Saleh \\ Mohammad $^{2}$,Ammar subhy Shaker ${ }^{2}$, Hawraa G.T.Al-Shebani ${ }^{2}$ and Asmaa Mohammed D. $\mathrm{K}^{2, \mathrm{c})}$
}

\author{
${ }^{1}$ Faculty of Agriculture, University of Aleppo, Syria. \\ ${ }^{2}$ Faculty of Agriculture, University of Al-Qadisiah, Iraq. \\ ${ }^{a)}$ Corresponding Author: : mahdi.mohammad@qu.edu.iq \\ b) omardenli@gmail.com \\ c)ama529365@gmail.com
}

Received : $12 / 11 / 2021$

Acceptance : $28 / 12 / 2021$

Available online: $31 / 12 / 2021$

\begin{abstract}
The research was conducted at the Research Center of Agriculture Faculty of the University of Aleppo. 240 chickens of Babcock B300 strain were used and distributed randomly from day one into four independent groups. Each group included 60 birds distributed into three replicates (20 birds). The control group (A group) was fed a balanced standard feed mixture (1-18 weeks) without additives, while lactic acid bacillus was added to treatments groups according to three levels ( $50 \mathrm{mg} / \mathrm{kg}$ feed; B group, $100 \mathrm{mg} / \mathrm{kg}$ feed; $\mathrm{C}$ group and $150 \mathrm{mg} / \mathrm{kg}$ feed; D group). Haematological analyzes were performed over two- time intervals (1-21 weeks and 22-32 weeks). In the first time interval, results showed that a rise in blood albumin $(\mathrm{P}<0.001)$ was also observed in $\mathrm{C}$ and $\mathrm{D}$ groups compared to the A group. The rates of blood globulin increased $(\mathrm{P}<0.02)$ in the $\mathrm{D}$ group compared with the rest of the groups. No significant differences were noticed across the various groups for the total number of white blood cells and lymphocytes rates. In the second time interval (productive stage), significant differences $(\mathrm{P}<0.01)$ were noticed across the various groups in the percentages of the total protein (the highest value was $4.75 \mathrm{~g} / \mathrm{dl}$; B group) and serum albumin (the highest value was $3.26 \mathrm{~g} / \mathrm{dl}$; D group). It is concluded from the current study that the addition of probiotics to the mixtures of laying hens had a significant improvement in the immune parameters in the blood.
\end{abstract}

Keywords. Lactic acid bacillus, Laying hens, Immunological parameters.

\section{INTRODUCTION}

The progress in the poultry industry has been linked to the interdependence of many scientific disciplines, such as reproductive physiology, nutrition and animal breeding [1-3]. Recently, the use of probiotics including the probiotic lactic acid bacillus has spread as a result of the problems related to the use of antibiotics as growth stimulants in poultry feed mixtures and the emergence of some bacterial strains such as salmonella and Escherichia coli, which threaten the poultry health.

It has been proven that the residual effects of antibiotics in poultry meat and products lead to many health problems for consumers, such as the increase in the formation of some bacterial strains that are resistant to antibiotics, which may lead to the ineffectiveness of some antibiotics as a result of exposure to low levels of these antibiotics in food, meat and eggs, which can cause some diseases such as tumors, kidney and liver failure [4].

Adding probiotics to poultry feed mixtures contributes to creating ideal living conditions in the intestines. Probiotics are provided through feed, spray or water [5]. It has been proven that probiotics have an important role in improving the bodyweight rate, the efficiency of feed conversion, reducing mortality rates and enhancing the body's immunity towards diseases [6]. Consequently, it was confirmed that the chicken feed mixture containing probiotics did not affect the feed consumption rate, feed conversion factor and live weight [7]. [8], showed that the addition of probiotics did not plasma albumin, plasma cholesterol and some minerals $(\mathrm{Mg}, \mathrm{Cl}$, and $\mathrm{Na}$ ) in plasma, while an increase in the percentage of total protein in egg albumin was observed. In sum, it can be said that the use of lactic acid probiotics in feed mixtures for laying hens is still under study, and the results reported by several studies are differential and the appropriate proportions of lactic acid probiotics added to laying hens' feed mixtures, whether in the care stage or the production stage, have not yet been determined. Therefore, it was necessary to conduct more research to reach the appropriate ratios in terms of impact on the immune and haematological characteristics, especially in the local conditions of the Syrian Arab country. Hera, in our current study, we sought to highlight the possibility of using lactic acid bacillus as growth-stimulating and immune-boosting feed additives as an alternative to common antibiotics. Also, studying the effect of adding lactic acid bacilli on some indicators of immunity. 


\section{MATERIALS AND METHODS}

\section{- Experimental Design}

240 birds of Babcock hybrid female laying hens were used and randomly distributed since the first day of the experiment into four independent and identical groups (A, B, C and D) isolated from each other by a metal net, each group included 60 birds according to three replicates (20 birds in each). One group was a control (A) while bacillus lactic acid was added in concentrations of $50 \mathrm{mg} / \mathrm{kg}, 100 \mathrm{mg} / \mathrm{kg}$ and $150 \mathrm{mg} / \mathrm{kg}$ to the feed mixtures of B, C and D groups respectively. Traits of some blood indicators of laying hens in all groups were studied as follows: total protein, albumin and globulin (g/dl) were analyzed using the Olympus-AU400 device, which depends on the principle of kinetic photo chromatography resulting from the chemical reaction (estimating the concentration of the reactant that produced the color).

\section{- Breeding System and Care}

The birds were placed in an open-ground breeding pen $\left(10 \times 50 \mathrm{~m}^{2}\right)$ with a gabled roof and painted from the inside (east, west). The ventilation was through the side windows.

\section{- Nutrition}

Table 1 shows the composition of the feed mixture used in feeding according to the standard needs of laying hens.

TABLE 1. Composition of the feed mixture provided to the birds of the experimental groups.

\begin{tabular}{cccc}
\hline Fodder Component & $\mathbf{1 - 6 0}$ days & $\mathbf{6 1 - 1 5 0}$ days & 151-224 days \\
\hline Maize & 69 & 67 & 61.6 \\
Soybean meal & 25 & 25 & 14.8 \\
Meat and bone meal & 2 & 2 & - \\
Dicalcium Phosphate & 1.5 & 1.5 & 10.8 \\
Calcium carbonate & 1 & 1 & - \\
NaCl & 0.5 & 0.5 & 0.3 \\
Premix Vitamins & 0.5 & 0.5 & 0.1 \\
Premixes & 0.5 & 0.5 & 0.1 \\
Limestone & - & 2 & 7 \\
Methionine & - & - & 0.1 \\
Choline chloride & - & - & 0.1 \\
\hline
\end{tabular}

Each one kilogram (powder) of lactobacillus probiotic contained the following:

- $10^{10}$ Lactobacillus acidophilus.

- $10^{10}$ Bacillus subtilus.

- $10^{10}$ Lactobacilli.

Table 2 shows the chemical composition of the aforementioned feed mixture.

TABLE 2. Chemical composition of the feed mixture provided to the birds of the experimental groups.

\begin{tabular}{cccc}
\hline & 1-60 days & $\mathbf{6 1 - 1 5 0}$ days & 151-224 days \\
\hline Energy (kcal) & 2900 & 2800 & 2701 \\
Components $(\%)$ & & & \\
Protein & 21.00 & 21.00 & 16.30 \\
Calcium & 1.05 & 1.00 & 2.00 \\
Phosphorous & 0.48 & 0.45 & 0.45 \\
Sodium & 0.18 & 0.17 & 0.16 \\
Chlorine & 0.20 & 0.19 & 0.18 \\
Lysine & 1.20 & 1.00 & 0.85 \\
Methionine + Cysteine & 0.83 & 0.70 & 0.68 \\
Arginine & 1.26 & 1.05 & 0.92 \\
Tryptophan & 0.23 & 0.21 & 0.20 \\
Threonine\% & 0.80 & 0.70 & 0.60 \\
Leucine & 1.55 & 1.30 & 1.05 \\
Isoleucine & 1.00 & 0.83 & 0.77 \\
Linoleic Acid & 1.40 & 1.40 & 1.00 \\
\hline
\end{tabular}


Blood samples were collected at $20 \%$ of each group at the end of each stage at an average of 12 birds. Blood was aspirated from the bird's wing vein in an amount of $10 \mathrm{ml}$ for each blood sample. Blood samples were placed in clean, sterile and numbered tubes with a tight plastic cap. The blood samples were divided into two equal parts:

The first part of the tubes contained anticoagulant ethylene diamine tetraacetic acid Dipotassium (E.D.T.A) at a concentration of $1 \mathrm{mg} / \mathrm{mL}$ blood to determine the white blood cell and lymphocyte counts. The second part of the tubes was placed in the blood without the addition of an anticoagulant to obtain the blood serum after coagulation. The tubes were left for one hour in the external temperature to complete the blood coagulation process. Next, the tubes were transferred to the laboratory directly at $4^{\circ} \mathrm{C}$ and centrifuged with a capacity of $3000 \mathrm{rpm}$ for a period of 15 minutes to obtain blood serum for biochemical analyzes (total protein, albumin, globulin).

\section{- White Blood Cell (W.B.C) Count}

White blood cell count was performed using an improved Neubauer counter using Turk's dilation solution at a dilution ratio of $1 / 20$ and the number was estimated to be $1000 \mathrm{cell} / \mathrm{mm}^{3}$.

\section{- Lymphocytes Count}

a smear of blood was put on a slide and left to dry. The samples were stained with Leishmain stain for 3 minutes, immersed in Leishmain stain buffer for 10 minutes, washed with water and left to dry.

\section{- Statistical Analysis}

Statistical analyzes were carried out using complete random design (CRD) to study the effect of treatment on the studied traits using (9) program. The differences between means were tested using Duncan's multilevel test at 0.05 and 0.01 .

\section{RESULTS AND DISCUSSION}

Upon the first stage of care (1-21 weeks), it is noted that the percentages of total protein in the blood serum of the groups treated with lactic acid bacteria were significantly $(\mathrm{P}<0.009)$ superior compared to the control group, as the percentage of blood protein in B and C groups reached the values $4.90 \mathrm{~g} / \mathrm{dl}$ and $4.85 \mathrm{~g} / \mathrm{dl}$ respectively, while the percentage of blood protein in the control group was $4.32 \mathrm{~g} / \mathrm{dl}$. On the other hand, group D outperformed its counterparts $(5.37 \mathrm{~g} / \mathrm{dl})$ (Table 3$)$.

The results of the research were in line with the results of [10]. The increase in the percentage of total protein in the blood plasma is attributed to increasing the production of amino acids produced by lactobacilli and the absorption of bacterial lysine by the body [11]. It increases the readiness of the nutrients and thus improves absorption inside the gastrointestinal tract, which increases the body's ability to benefit from the nutritional components especially crude protein [12].

Looking at the results of serum albumin ratios in the previous table, it is noted that there are significant differences $(\mathrm{P}<0.001)$ among the treated groups compared with the control group. The proportion of blood albumin were $1.51,1.59 \mathrm{and} 1.77 \mathrm{~g} / \mathrm{dl}$, while the proportion of albumin in the control group was $1.43 \mathrm{~g} / \mathrm{dl}$. The results of the current study were in agreement with the results of $[13,14]$.

As for serum globulin, the previous table shows that no significant differences were noticed across the birds of the groups treated with lactic acid bacillus compared with the control group. The values of globulin in the A, B and C groups were 1.91 $\mathrm{g} / \mathrm{dl}, 1.89 \mathrm{~g} / \mathrm{dl}$ and $1.85 \mathrm{~g} / \mathrm{dl}$. On the other hand, the results showed a significant difference $(\mathrm{P}<0.02)$ between the $\mathrm{A}$ and $\mathrm{C}$ groups, as the value was $2.31 \mathrm{~g} / \mathrm{dl}$ (D group)

Probably, this increase is attributed to the role of lactic acid bacilli in stimulating the immune system and the production of antibodies. Thus increasing the production of gamma globulin [15]. The current results are consistent with the findings of [16,17], while the current results did not agree with what was shown by [18].

The total number of white blood cells were not significantly affected by the feed additives. The total numbers of white blood cells in the B, C and D groups were 24710 cell $/ \mathrm{mm}^{3}, 23960 \mathrm{cell} / \mathrm{mm}^{3}$ and $23820 \mathrm{cell} / \mathrm{mm}^{3}$, respectively compared with the control group $\left(24170 \mathrm{cell} / \mathrm{mm}^{3}\right)$. [19], found results that are very close to ours, in contrast to the results of [20].

Table 3 also shows the results of the statistical analysis of lymphocyte ratios across the white blood cells, which indicates that there are insignificant differences between the percentages of lymphocytes across different groups of birds. Accordingly, our results paralleled those of [21], while they were opposite to those of [22]. 
TABLE 3. Effect of adding three levels of lactic acid bacteria to the feed mixture on the blood parameters (1-21 weeks)

\begin{tabular}{|c|c|c|c|c|c|}
\hline \multirow{3}{*}{ (Total protein $\mathrm{g} / \mathrm{dl}$ ) } & \multicolumn{4}{|c|}{ Groups } & \multirow{2}{*}{ Prob } \\
\hline & $\mathbf{A}$ & B & $\mathbf{C}$ & D & \\
\hline & $\begin{array}{c}\mathrm{b} \\
4.32 \pm 0.08\end{array}$ & $\begin{array}{c}\mathrm{a} \\
4.90 \pm 0.15\end{array}$ & $\begin{array}{c}\mathrm{a} \\
4.85 \pm 0.17\end{array}$ & $\begin{array}{c}\mathrm{a} \\
5.37 \pm 0.32\end{array}$ & 0.0009 \\
\hline Albumin (g/dl) & $\begin{array}{c}\mathrm{b} \\
1.43 \pm 0.03\end{array}$ & $\begin{array}{c}\mathrm{b} \\
1.51 \pm 0.02\end{array}$ & $\begin{array}{c}\mathrm{ab} \\
1.59 \pm 0.05\end{array}$ & $\begin{array}{c}\mathrm{a} \\
1.77 \pm 0.06\end{array}$ & 0.001 \\
\hline Globulin (g/dl) & $\begin{array}{c}b \\
1.91 \pm 0.01\end{array}$ & $\begin{array}{c}\mathrm{b} \\
1.89 \pm 0.01\end{array}$ & $\begin{array}{c}\mathrm{b} \\
1.85 \pm 0.03\end{array}$ & $\begin{array}{c}\mathrm{a} \\
2.31 \pm 0.21\end{array}$ & 0.02 \\
\hline $\begin{array}{l}\text { White Blood Cell } \\
\left(1000 \text { cell } / \mathrm{mm}^{3}\right)\end{array}$ & $\begin{array}{c}\mathrm{b} \\
24.17 \pm 0.32\end{array}$ & $\begin{array}{c}\mathrm{b} \\
24.71 \pm 0.70\end{array}$ & $\begin{array}{c}b \\
23.96 \pm 0.37\end{array}$ & $\begin{array}{c}\mathrm{b} \\
23.82 \pm 0.70\end{array}$ & N.S \\
\hline $\begin{array}{c}\text { Lymphocytes count } \\
(\%)\end{array}$ & $\begin{array}{c}\mathrm{b} \\
51.34 \pm 1.83\end{array}$ & $\begin{array}{c}\mathrm{b} \\
53.47 \pm 2.47\end{array}$ & $\begin{array}{c}\mathrm{b} \\
55.35 \pm 3.17\end{array}$ & $\begin{array}{c}\mathrm{b} \\
55.49 \pm 2.68\end{array}$ & N.S \\
\hline
\end{tabular}

\footnotetext{
a, b Means in the same row with no common superscripts are significantly different $(\mathrm{P}<0.05), \mathrm{A}:$ control, $\mathrm{B}: 50 \mathrm{mg} / \mathrm{kg}, \mathrm{C}: 100$ $\mathrm{mg} / \mathrm{kg}, \mathrm{D}: 150 \mathrm{mg} / \mathrm{kg}$.
}

During the period between the 21 and the 32 weeks (Table4), the results of the statistical analysis of the total protein in the serum of the studied birds indicate that there is a significant superiority $(\mathrm{P}<0.011)$ in the percentage of total protein of the groups (4.75 g / $100 \mathrm{ml}$; B group, $4.65 \mathrm{~g} / 100 \mathrm{ml}$; C group and $4.80 \mathrm{~g} / 100 \mathrm{ml}$; D group) compared with the control group (4.05 g / $100 \mathrm{ml}$; A group).

From the above, the positive effect of lactic acid bacilli in raising the percentage of total protein is highlighted, which is consistent with the findings of [23], as the results of Alkhalf et al. (2010) see otherwise.

The previous Table shows a significant superiority in the albumin ratio $(\mathrm{P}<0.0001)$ across the various groups of birds. The values in the two groups (B and C groups) were $2.62 \mathrm{~g} / 100 \mathrm{ml}$ and $3.24 \mathrm{~g} / 100 \mathrm{ml}$, respectively, while the value recorded in the control group was $1.99 \mathrm{~g} / 100 \mathrm{ml}$.

The results of the study agreed with the findings of [24] and Tortuero and [25], while the results of the study did not agree with the results of $[8,26]$.

TABLE 4. Effect of adding three levels of lactic acid bacteria to the feed mixture on the blood parameters (22-32 weeks).

\begin{tabular}{cccccc} 
& \multicolumn{4}{c}{ Groups } & \multirow{2}{*}{ Prob } \\
\cline { 2 - 5 } & A & B & C & D & \\
\cline { 2 - 5 } Total protein $(\mathrm{g} / \mathrm{dl})$ & $\mathrm{b}$ & $\mathrm{a}$ & $\mathrm{a}$ & $\mathrm{A}$ & \multirow{2}{*}{0.01} \\
& $4.05 \pm 0.20$ & $4.75 \pm 0.20$ & $4.65 \pm 0.29$ & $4.78 \pm 0.10$ & \\
Albumin $(\mathrm{g} / \mathrm{dl})$ & $\mathrm{b}$ & $\mathrm{a}$ & $\mathrm{a}$ & $\mathrm{A}$ & \multirow{2}{*}{0.0001} \\
& $1.99 \pm 0.12$ & $2.62 \pm 0.10$ & $3.24 \pm 0.23$ & $3.26 \pm 0.25$ & \\
\hline
\end{tabular}

${ }^{\mathrm{a}, \mathrm{b}}$ Means in the same row with no common superscripts are significantly different $(\mathrm{P}<0.05), \mathrm{A}: \mathrm{control}, \mathrm{B}: 50 \mathrm{mg} / \mathrm{kg}, \mathrm{C}: 100$ $\mathrm{mg} / \mathrm{kg}, \mathrm{D}: 150 \mathrm{mg} / \mathrm{kg}$.

\section{CONCLUSION}

It concluded that the addition of lactic acid bacilli in the laying hens' feed mixture led to an increase in the percentage of total protein, albumin and immunoglobulin.

\section{REFERENCES}

[1] Mohammad Al-Kerwi, M.S., Amin Al-Tawash, A.S., Salah Almrsomi, T.2020. Comparison the Effect of Adding Waterly Extract of Black Seeds (Nigella Sativa), Chamomile and Fenugreek with Drinking Water on Productive Performance for Broiler. IOP Conference Series: Earth and Environmental Sciencethis, 553(1), 012043.

[2] Almrsomi, T.S., Areaaer, A.H., Mohammad, M.S.2021. Influence of addition different levels of ginger powder in diet on productive performance of broiler ross. Indian Journal of Ecologythis , 2021, 48, pp. 6-9.

[3] AL-Tawash, A.S.A., Suwaihi, T.A., Mohammad, M.S., Mohsen, A.A.2020. Beneficial effects of chrysin and ginger on blood biochemical parameters, hematology and immune response of broilers. Plant Archivesthis , 2020, 20, pp. $215-219$.

[4] Reuter G.; 2001- Probiotics - Possibilities and Limitations of their application in food, animal feed, and in pharmaceutical preparations for man and animals. Ber. Mun. Tier. Woch. 1(14): $410-419$.

[5] Schneitz C.; 1993- Development and evaluation of a competitive exclusion product for poultry. Ph. D. Thesis, University of Helsinki, Department of Veterinary Medicine, Helsinki, Finland. 


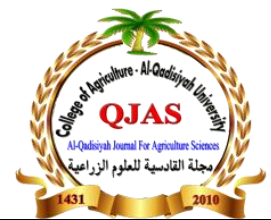

[6] Mountzouris KC, Tsirtsikos P, Kalamara E, Nitsch S, Schatzmayr G, Fegeros K .2007.Evaluation of the efficacy of a probiotic containing Lactobacillus, Bifidobacterium, Enterococcus and Pediococcus strains in promoting broiler performance and modulating cecal microflora composition and metabolic activities. Poult. Sci. 3(86): 309-317.

[7] Aghaei, A.S.M., M. Chaji and M. Nazari, 2010. Effect of dried whey (probiotics) and prebiotics in laying hens' performance and intestinal Flora. J. Anim. Vet. Adv.,5(9): 1996-2000. supplementation on blood parameters and growth performance in broiler chickens. Saudi Journal of Biological Sciences 17(3): 219-225.

[8] Ahmet G. Nol, Mustafa Sarı, Fatma Karakaş Oğuz, Beyhan Gülcan, G.Ksel Erbaş. 2003.The Effects of Dietary Probiotic Supplementation on Some Productivity and Blood Parameters of Laying Quails Raised under Constant Heat Stress. Turk J Vet Anim Sci 27 (2003): 1397-1402.

[9] SPSS. (2019). Static Analysis program, version 9.00.

[10] Jin, L.Z,Y.W.Ho;N.Abdullah And S.Jalaludin. 2002- Digestive and bacterial enzyme activities in broilers fed diets supplemented with lactobacillcultures. Poultry sci, 3(79): 886-891.

[11] Petzke, K.J. ; J.G. Grigorov ;O.V. Korkushko ; N.K. Kovalenko ;T.G. Semesko And C.C. Metges 1998- Incorporation of urea nitrogen into fecal protein and plasma protein amino acid in elderly human volunteers after ingestion of lactic acid bacteria .Z.Ernahrung.37(4):368-375.

[12] Gibson GR 2007-.Functional Foods : Probiotics and Prebiotics food Microbial Sciences Unit ,Department Of Food Biosciences ,The University of Reading ,UK Poultry sci.2(28): 965- 989.

[13] Azza H. Abd-El-Rahman, H.H. Kamel, Walaa M. Ahmed, Olfat S.H. Mogoda and Amira H.Mohamed. 2012- Effect of Bactocell ${ }^{\circledR}$ and Revitilyte-Plustm as Probiotic Food Supplements onthe Growth Performance, Hematological, Biochemical Parameters and Humoral Immune Response of Broiler Chickens. World Applied Sciences Journal 18(3): 305-316 2012.

[14] Alkhalf A., M. ALhaj and I. AL-Homidan., 2010-. Influence of probiotic supplementation on blood parameters and growth performance in broiler chickens. Saudi Journal of Biological Sciences 17(3): 219-225.

[15] Sarinee K, Tnongong TB, Chavahanikual V. 2008- Blood naematologic alcholeterol profile and antibody titer tespone of broiler with added probiotics containing both bacteria and yeast an or antibiotics in drinking water. thai. J Vet Med 38(4): 45-56.

[16] Ibrahim, K. A., Mahmoud Faten, A. and Abd Elhalim Haiam, S. 2005- Comparison of the efficacies of commercial probiotics on growth performance, carcass characteristics and some plasma constituents of broiler chicks. Suez Canal Veterinary Medicien Journal, (VIII): 1-18.

[17] Along T, Raji M.A, Hassan B.F, Kawu M.U, Kobo P.I and Ayo J.O .2012. Effect of different levels of supplemental probiotic on performance indicesand serum biomarkers of broiler chickens. International Conference and Exhibition on Probiotics - 2012. Hilton San Antonio Airport, USA

[18] Haghighi HR, Gong J, Gyles C, Hayes A, Sanei B, Parvizi P, Gisavi H, Chambers JR, Sharif S (2005). Modulation of Antibody-Mediated Immune Response by Probiotics in Chickens. Clin. Diagnostic Lab. Immunol., 12(12): 1387-1392.

[19] Zou, S. G., And Wu,Y. Z. 2005- Effect of supplemental fat on performance of 273 laying hens. Int. J. Poult. Sci., 4:9981000 .

[20] Salim, H.A, Abd-Allah, O. A., And Fararh, K.M. 2011-. Effect of feeding probiotic on hematological biochemical properties and immune response in broiler. benha veterinary medical journal, 22(2): 35-43.

[21] Zarei Mohammad, Mohammad Ehsani and Mehran. 2011- Dietary Inclusion of Probiotics, Prebiotics and Synbiotic and Evaluating Performance of Laying Hens. American Journal of Agricultural and Biological Sciences 6(2): 249-255.

[22] Khaksefidi A., Rahim Sh 2005- Effects of Probiotic Inclusion in the Diet of Broiler Chickens on Performance, Feed Efficiency and Carcass Quality. Asian-Aust. J. Anim. Sci., 18(8): 1153-1156.

[23] Zangana, B. S. R.; AL-Hajo, N. N. A., 2009- A comparative study on the effect of locally produced probiotic, prebiotic and synbiotic on egg chemical composition and egg serum cholesterol of White Leghorn hens. Journal Egyptian Journal of Nutrition and Feeds. 12:(1). 177-185

[24] Hayirli A, N. Esenbuğa, M. Macit1, M. A. Yörük, A. Yildiz AND H. Karaca., 2005- Nutrition practice to alleviate the adverse effects of stress on laying performance, metabolic profile and egg quality in peak producing hens: II. The probiotic supplementation. Asian-Aust. J. Anim. Sci.. Vol 18, No. 12:1752-1760).

[25] Tortuero, F., Fernández, E., 1995- Effects of inclusion of microbial cultures in barley-based diets fed to laying hens. Anim. Feed. Sci. Tech. 53:255-265.

[26] Yousefi.M and K.Karkoodi., 2007-Effect of Probiotic and Saccharomyces cerevisiae Supplementation on performanace and Egg Quality of Laying Hens., International of Poultry Science 6(1):52-54. 